\section{Co-learning, translanguaging and English language acquisition}

The US has the largest in the world but its is a akers multilingual: according to 2018 aged 5 to 17 speak another language at home. English who speak English as a second language is therefore an Mary Amanda Stewart and Woman's University have bea studying how 'translanguaging' and 'co-learning' can be used to help newcomer English language learners acquire greater fluency. census data, $23 \%$ of children language acquisition for those important issue for educators. t used to be thought that total

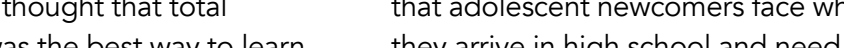
a second language and that students learn best when the target language is the only language used in the is the only language used in the $\quad$ They argue that "in the race to acquire grade level skills in a second language, $\begin{array}{ll}\text { guages should } & \text { students' (own) rich language practices } \\ \text { are often overlooked". }\end{array}$ be regarded as assets in the armour respected as key features of studen ts . shows the benefits of 'translanguaging' in the classroom, whereby immigrant students who speak English as a second language are encouraged to make use English. The approach takes as its english. The approach takes as its have an innate wealth of knowledge about language which can be used to suppoct can as English language learners in bilingual and multilingual environments. The study by Dr Stewart and Dr Holly HansenThomas of Texas Woman's University highlights the particular
challenges hat adolescent newcomers face when pass the tests needed to graduate.

As part of their research, Dr Stewart and Dr Hansen-Thomas held and observed an optional English language summer institute for students of a high school in a mid-sized town in Texas with almost a quarter of Spanish-speaking residents. The aim was to study how Enslanguaging can be used to help greater literacy and fluency.

The summer institute was taught by two teachers, who, like the majority of American high school educators, were monolingual and had limited training. in bilingualism or multilingualism, or experience of teaching using translanguaging. A second aim of the study was therefore to look at how monolingual teachers enact a tacilitate the process by becoming colearners with their students.

CONTEXT AND METHOD DrStewart and Dr Hansen-Thomas's summer institute. Five were studied in detail for the qualitative research
New research from the United States hey arrive in high school and need

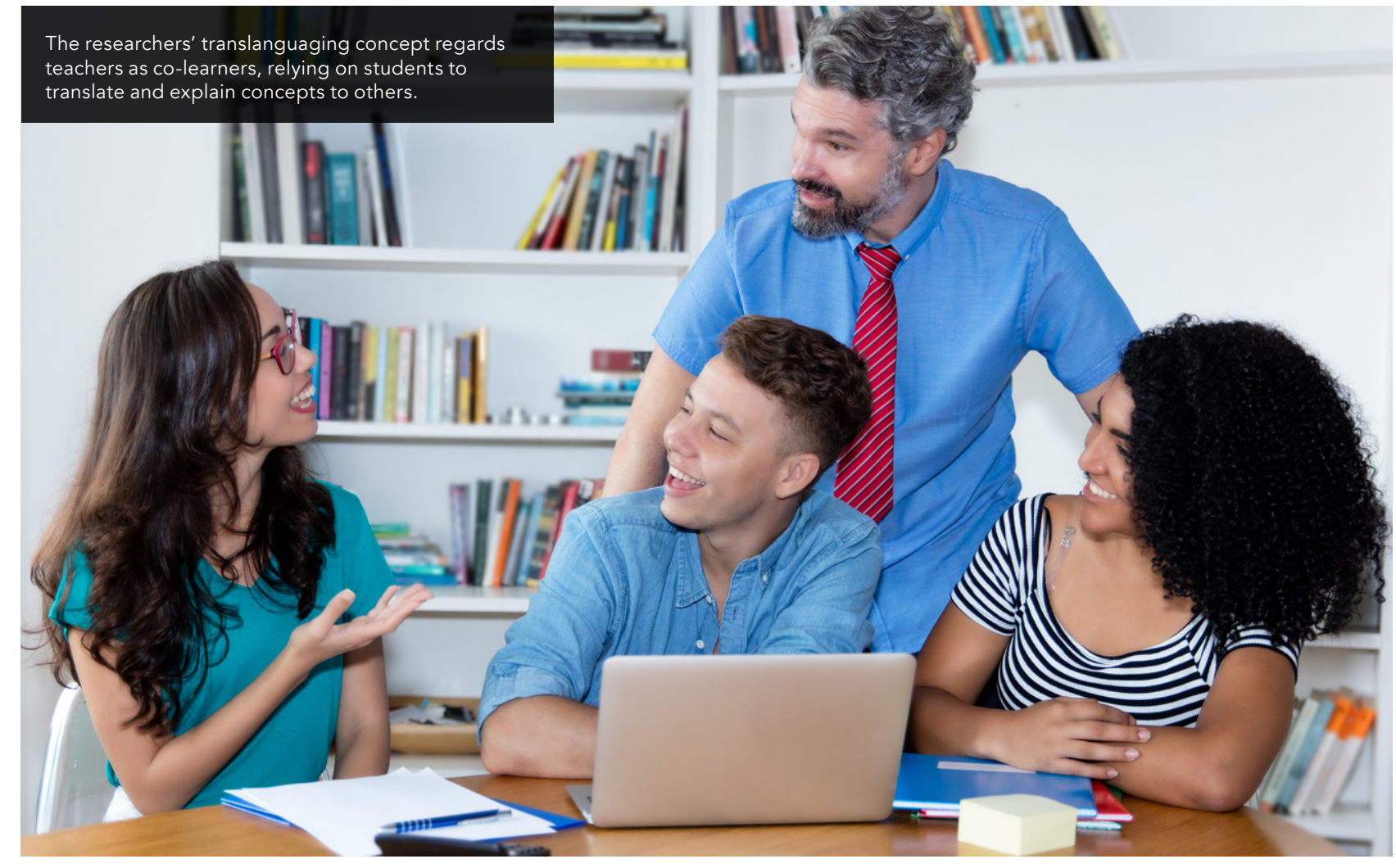

programme. Aged 16 to 18 and originally from South America, their primary language was Spanish and they honth and three years.

Two teachers also took part. Both were white females, aged between 40 and 60. Committed educators who were also pursuing doctorates, they had 13 and 14 years' teaching experience respectively.
Prior to the study they read one book Prior to the study the
on translanguaging contained sample lesson templates.

The institute met for three days a week over six weeks,

giving students

45 hours of teacher contact time. Dr Stewart, who spoke English and Spanis monitored lessons and provided insight into what students were saying to one another in their native tongue. In addition to collecting data, she worked with the teachers to continually modify their instruction, for example modelling ways to invite students to use their own lat of the summer institure the Aeachers the classes, using whichever language

Both teachers and students made use of Translate, mobile phone applications, Resources chor internet research. Resources chosen by teachers for literacy activites included multilingua texts such as poems and stories. on students' lived experiences. They

In the race to acquire grade level skills in a second language, students' rich (own) language practices are often overlooked. were invited to create 'heart maps' labelled visual representations of what mattered most to them, 'graffiti walls which allowed them to make a person connection to a text using words or drawings, and digital presentations in which they told the class about themselves and their backgrounds.

Data collected and analysed for the study included teachers' daily field notes and reflections, Dr Stewart's observations, students' reflections, work samples.

FINDINGS The data was that The

Although open to the idea of inviting . of the classes their attitudes changed. attitudes changed
The researchers also noted that as a result of the classes, the two teachers said that "their knowledge of world events, immigration policies and even their own privilege increased greatly"

The teachers positioned themselves as co-learners in the classes. Making clear that they "were not the sole possessors of knowledge, and setting aside their concerns that it placed a burden on English learers, they relied onced English learners, hey relied on thes students to translate and explain
concepts for others when needed. 


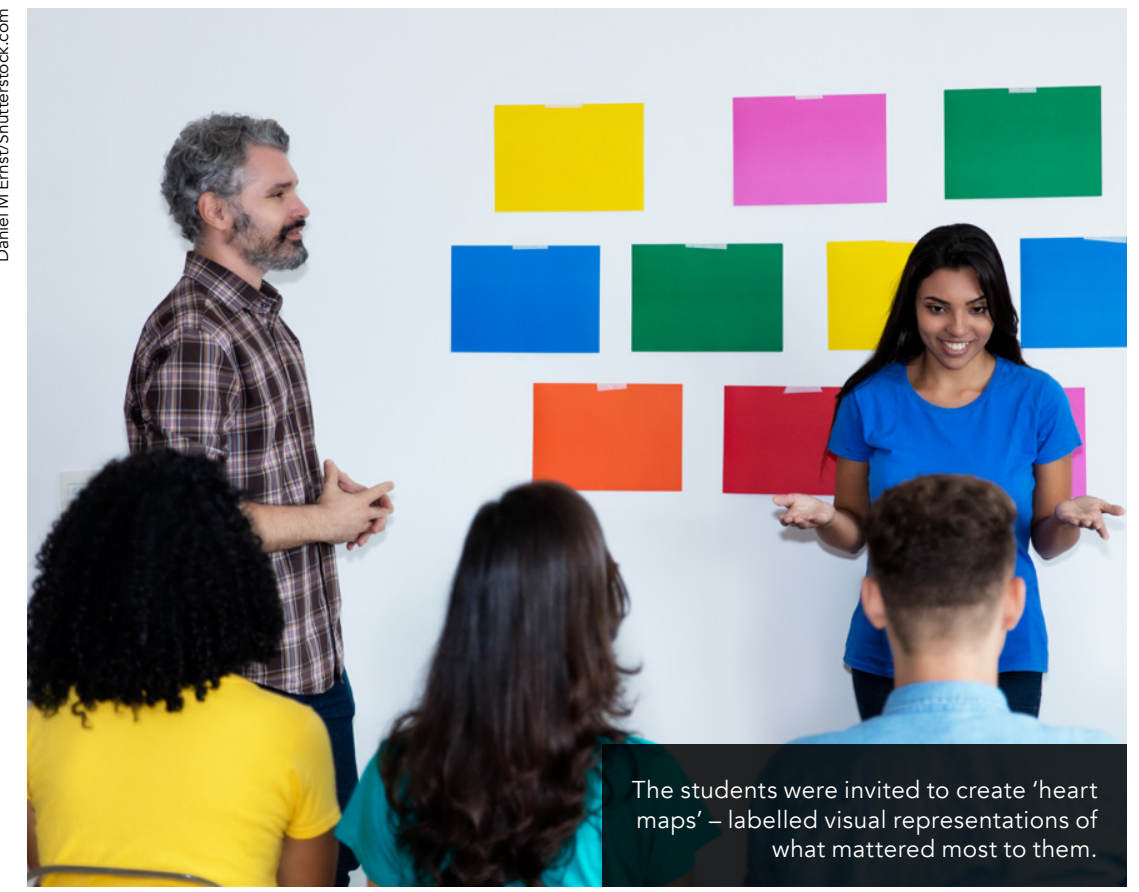

A teacher stated: "Translanguaging was like a key to help unlock meaning through negotiating with the students."

Not only did the teachers acknowledge that students enjoyed their roles as "language brokers", they saw that it helped to improve their own English because they needed to understand words and concepts more deeply and asked questions before translating. The researchers noted: "This facilitate the students to actively participate in clarifying content for one another their language."

The study cites one example when determine the working together to poem. One teacher noted: "Even though one student quickly found the Spanish translation on her phone ('invariable') and noted it was a cognate, they spoke for two full minutes in Spanish among themselves to determine what the word really meant in the context in which it was presented. Athough technology and multilingual texts assisted in creating this translanguaging space, the students relied more heavily on each othe "

The teacher also noted:

"Translanguaging was like a key to help unlock meaning through negotiating summer institute: "Thave foud that student did not best meet students" needs." In order to get student buyin, the teacher had to overcome the provider of knowledge.
Students reported that they had taken their English skills. However, the researchers noted some tension in esponse to translanguaging because although students "came alive" and "engaged more" when speaking their first language alongside English, some said they wanted to use more English in class and others felt that they shouldn't have been allowed to use mobile phones and computers to help them.

\section{CONCLUSION}

Dr Stewart and Dr Hansen-Thomas

argue that translanguaging can be a

catalyst for learning. They propose that

to address the "growing linguistically

diverse secondary English language

stanguaging teaching should be

useachers who do not speak all thir

students' first languages, as well as by

bilingual teachers.

The team argues that their study shows how even monolingual teachers can use translanguaging approaches and implement pedagogical practices that are socially and culturally relevant to English learners, provided they rethink traditional teacher/student roles and are open to the use in the classroom of technology and translation devices such as mobile phones and laptops.

While recognising that students had mixed feelings about the use of the first languages in the classroom, Dr that co-learning offers a way formeleve They explain: "Students' voices need to be central as teachers continually reflect on how and when to invite students' first languages into sanctioned

medium classrooms."

They conclude: "Like translanguaging, co-learning can be an equalising pedagogy that can put the teacher and students on the same level in regard to holders of knowledge that is worthy of sharing. As we consider how to create more equitable learning spaces for adolescent emerging bilinguals, we must push all educators to adopt co-learning practices that privilege

\section{Behind the Research}

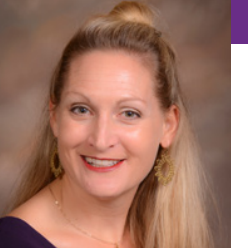

Dr Mary

Amanda Stewart
E: MStewart7@twu.edu

W: www.maryamandastewart.com

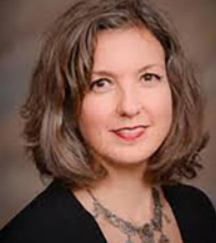

Dr Holly Hansen-Thomas E: HHansenThomas@twu.edu

W: https://bit.ly/2XSXzob

Whttps://twitter.com/hansen_holly

\section{Research Objectives}

Dr Stewart and Dr Hansen-Thomas research how co-learning through translanguaging might improve academic engagement and English language acquisition.

\section{Detail}

Mary Amanda Stewart

Denton
TX76204

USA

Mary Amanda Stewart and Holly Hansen-Thomas are faculty at Texas

\section{References}

Hansen-Thomas, H., Stewart, M.A., Flint, P. and Dollar, T. (2020). Co-learning in the High School English Class through Translanguaging: Emergent Blingual Newcomers \& Mducaingual Teachers. Joun al of Language, ldentry

Flint, P., Dollar, T., Stewart, M.A. (2019). Hurdling Over Language Barriers: Building Relationships with Adolescent B. Adolescent \& Adult Literacy, 62(5), 509-519.

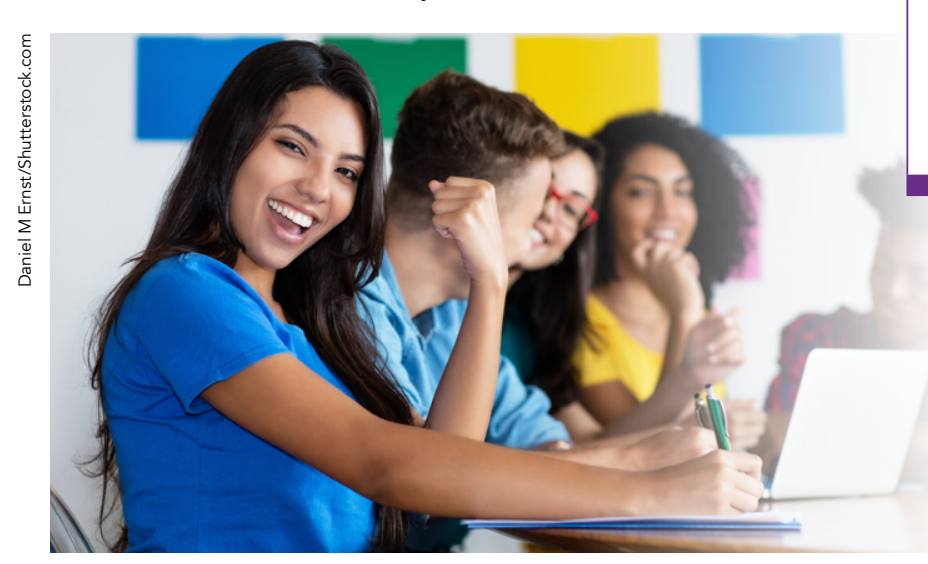
spaces in high school English-

Funding

U.S. Department of Education, Office of Professional Development Grants the U.S. Department of Education aimed at supporting emergent bilingual students. They have authored and edited multiple books

\section{Collaborators}

- Patricia Flint

- Tamra Dollar

- Liliana Grosso Richin

\section{Personal Response}

Some teachers might feel less in control if they don't allow students to use mobile phones in class. Does your research cast light on any behavioural issues that may arise in translanguaging classes?

Ir Giving up some control is important in translanguaging classroom, but that can happen as teachers adopt the stance as co-learners. The use of technology to translate should also be purposeful and
not necessarily used all the time. Sometimes, learners not necessarily used all the time. Sometimes, learners
need to negotiate meaning of the target language in context It is important that teachers begin to understand how translanguaging or bilingual theory supports

second language acquisition theory and then make solid
instructional decisions based on that knowledge.

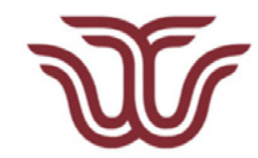

TEXAS WOMAN'S

UNIVERSITY for the High School Classroom' wit 